\title{
Térdközeli lateralis cystosus elváltozások differenciáldiagnosztikája
}

\author{
Szuper Kinga dr. ${ }^{1}$ - Giyab Omar dr. ${ }^{2}$ - Than Péter dr. ${ }^{1}$ \\ ${ }^{1}$ Pécsi Tudományegyetem, Általános Orvostudományi Kar, Klinikai Központ, Ortopédiai Klinika, Pécs \\ ${ }^{2}$ Pécsi Tudományegyetem, Általános Orvostudományi Kar, Klinikai Központ, Radiológiai Klinika, Pécs
}

\begin{abstract}
A térdízület lateralis oldalán észlelt lágyrész-terimék differenciáldiagnosztikai nehézséget jelenthetnek. Bár ezek nagy része jóindulatú, többnyire cystosus jellegű megjelenésük, fokozott növekedési hajlamuk miatt tumor gyanúját is kelthetik. A szerzők közleményükben két ritka lágyrész-elváltozást mutatnak be három beteg esetének ismertetésével. Áttekintik a mindennapi ellátásban leggyakrabban alkalmazott diagnosztikai eljárásokat, bemutatják a mútéti lehetőségeket, valamint tárgyalják a téma irodalmát.
\end{abstract}

Orv Hetil. 2019; 160(15): 593-599.

Kulcsszavak: térd körüli lágyrész-cysták, differenciáldiagnosztika, MRI, ganglioncysta

\section{Differential diagnosis of lateral cystic lesions in the knee joint}

\begin{abstract}
Soft tissues detected on the lateral side of the knee joint may have differential diagnostic difficulties. Although most of these are benign, mostly cystic in appearance, they may raise the clinical suspicion of tumors due to their increased growth. The authors describe two rare soft tissue changes in three patients. They review the diagnostic procedures most commonly used in daily care, present surgical options, and discuss the literature of the subject.
\end{abstract}

Keywords: soft tissue tumor, knee, differential diagnosis, MRI, ganglion cyst

Szuper K, Giyab O, Than P. [Differential diagnosis of lateral cystic lesions in the knee joint]. Orv Hetil. 2019; 160(15): 593-599.

(Beérkezett: 2018. október 14.; elfogadva: 2018. november 19.)

\begin{abstract}
Rövidítések
CT = (computed tomography) számítógépes tomográfia; MR $=($ magnetic resonance $)$ mágneses rezonancia $; \mathrm{MRI}=$ (magnet ic resonance imaging) mágnesesrezonancia-képalkotás; PET = (positron-emission tomography) pozitronemissziós tomográfia; SINS = (spinal instability neoplastic score $)$ gerincinstabilitás neoplasztikus pontszám
\end{abstract}

A térdízület körüli lateralis cysták ritka entitásnak számítanak: irodalmi adatok szerint a lateralis meniscus cysták incidenciája 1,9-19,5\%, míg az intraarticularis ganglion cysták prevalenciája MR-vizsgálatokban 0,2-1,9\% [1-3]. $\mathrm{Az}$ infrapatellaris zsírszövetból eredő ganglioncysták melyek intaarticularis elváltozások ugyan, de szintén megjelenhetnek lateralis térdközeli duzzanatként - még ennél is ritkábbak, az irodalomban eddig csak néhány esetet közöltek $[4,5]$. A lateralis meniscus cysta első korai leírása 1883-ban Nicaise-től [6], majd 1904-ben Ebnertől származik [7]. Az első elülső keresztszalagból kiinduló gangliont 1924-ben Caan írta le [8].

A lateralis meniscus cystákat megjelenésük alapján intrameniscalis és parameniscalis cystákra oszthatjuk fel. Az intrameniscalis cysta a meniscuson belüli, ezzel szemben a parameniscalis cysta a meniscus mellett elhelyezkedő fokális ízületi folyadékgyülem. Mindkét cysta a meniscus szakadásával társul [9].

Etiológiájuk pontosan nem tisztázott; az irodalomban két elmélet ismert, a degeneratív és a traumás. Az első az intrameniscalis myxoid degenerációra helyezi a hangsúlyt, mely microcystaképződéshez vezet, ami időben fokozatos növekedést mutathat. A másik elmélet egy kezdeti meniscussérülést ír le egyirányú szelepképződéssel, ami a meniscus üregében synovialis folyadék felhal- 
mozódását teszi lehetővé, különösen álló helyzetben és a térd mozgásai során [10].

Klinikai megjelenésük alapján a lateralis meniscusból kiinduló meniscuscysták vagy tünetmentesek, vagy meniscusszakadás tüneteit mutatják. A lateralis meniscus parameniscalis cystái az esetek 20-60\%-ában tapinthatók. 90-98\%-ban kapcsolódnak horizontális komponenst mutató meniscusszakadáshoz, ezek vagy egyszerú horizontális szakadások, vagy olyan komplex szakadások, melyeknek horizontális komponensük is van $[9,11]$. Csonteróziót csak ritkán okoznak [12].

A ganglioncysták ismeretlen eredetű cystás tumorszerű elváltozások sûrű kötőszövetes tokkal, bennük zselatinos hialuronsavban és más, mukopoliszacharidokban gazdag folyadékkal [11, 13]. A ganglionokat hagyományosan a következő kategóriákba sorolhatjuk: intaaarticularis, extraarticularis, intraossealis és periostealis [13]. A ganglionok ritka esetben szintén megjelenhetnek lateralis térdduzzanat formájában, ez leginkább az intraarticularis, a Hoffa-zsírtestből kiinduló multilocularis ganglion cystákra jellemző.

$\mathrm{Az}$ intraarticularis ganglionok előfordulási aránya MRvizsgálatokban körülbelül 0,9-1,3\% [14]. A patogenezis vitatott, a legtöbb szerző szerint a ganglioncysták a kollagénállomány mucoid cystás degenerációjának következményei. A ganglionok olyan, állandó stressznek kitett területeken jelennek meg, mint az ízületi tok vagy a szalagok. Ismétlődő tevékenységek során ezeken a területeken a periarticularis kötőszövet mucoid degeneráción megy keresztül amorf zselatinos anyag képződése mellett [15]. Egy másik lehetséges elmélet szerint az ízületi tok vagy ínhüvely szakadásának synovialis herniatiójaként alakulnak ki $[2,16]$.

$\mathrm{Az}$ intaarticularis ganglion cysták általában a keresztszalagokból származnak, ritkábban a Hoffa-zsírtestból, elöl a ligamentum mucosumból, a térdízület hátsó septumából, a hátsó keresztszalag és a hátsó tok között [2]. $\mathrm{Az}$ intraarticularis ganglion cysták klinikai megjelenése függ a cysta méretétől és annak elhelyezkedésétől. A keresztszalag-ganglionok lokalizált fájdalmat, korlátozott térdízületi mozgást, ízületi elakadást és - ha extraarticularis kiterjedésük is van - tapintható csomót okozhatnak $[3,16]$.

A Hoffa-zsírtestben lévő ganglion tünetmentes lehet, vagy elülső térdfájdalmat okozhat az extensio végpontján, és nyomásérzékenységet a patellaínban. Általában nincs traumás előzmény vagy bizonyított ízületi instabilitás, és a legtöbb intraarticularis ganglionnál nincsenek kapcsolódó térdízületi belső zavarok [16].

Bár gyakoriságát tekintve mindkét elváltozás ritka, fizikális megjelenésük, valamint azon tulajdonságuk, hogy tapinthatók, akár rövid idő alatt jelentős növekedést mutató lágyrész-duzzanat, tumor gyanúját kelthetik. Fizikális vizsgálat alapján lényegében nem különíthetők el egymástól, diagnosztikájuk fóként MR-vizsgálaton alapul.

Tudomásunk szerint a magyar irodalomban térd körüli lágyrész-elváltozásokról eddig nem jelent meg közle- mény, illetve a magyar tankönyvek közül is csak egy foglalkozik ezzel bővebben [17], ezért kifejezetten fontosnak tartottuk a nemzetközi irodalom részletesebb áttekintését.

Közleményünkben két lateralis meniscus cystás, valamint egy intraarticularis ganglion cystás esetünket ismertetjük.

\section{Elsö eset}

A 40 éves férfi beteg 6 éve fennálló lateralis térdízületi panaszok miatt kereste fel ambulanciánkat. Anamnéziséből kiemelendő a 10 éve elesés következtében elszenvedett lateralis térdsérülés, mely miatt érdemi ellátás nem történt.

Fizikális vizsgálata során a lateralis ízrés felett, a fibulafejecs előtt, a tractus iliotibialis tapadása alatt igen kemény tapintatú, de nem csontosnak imponáló nyomásérzékeny terimét észleltünk a térd 45 fokos hajlítottságánál.
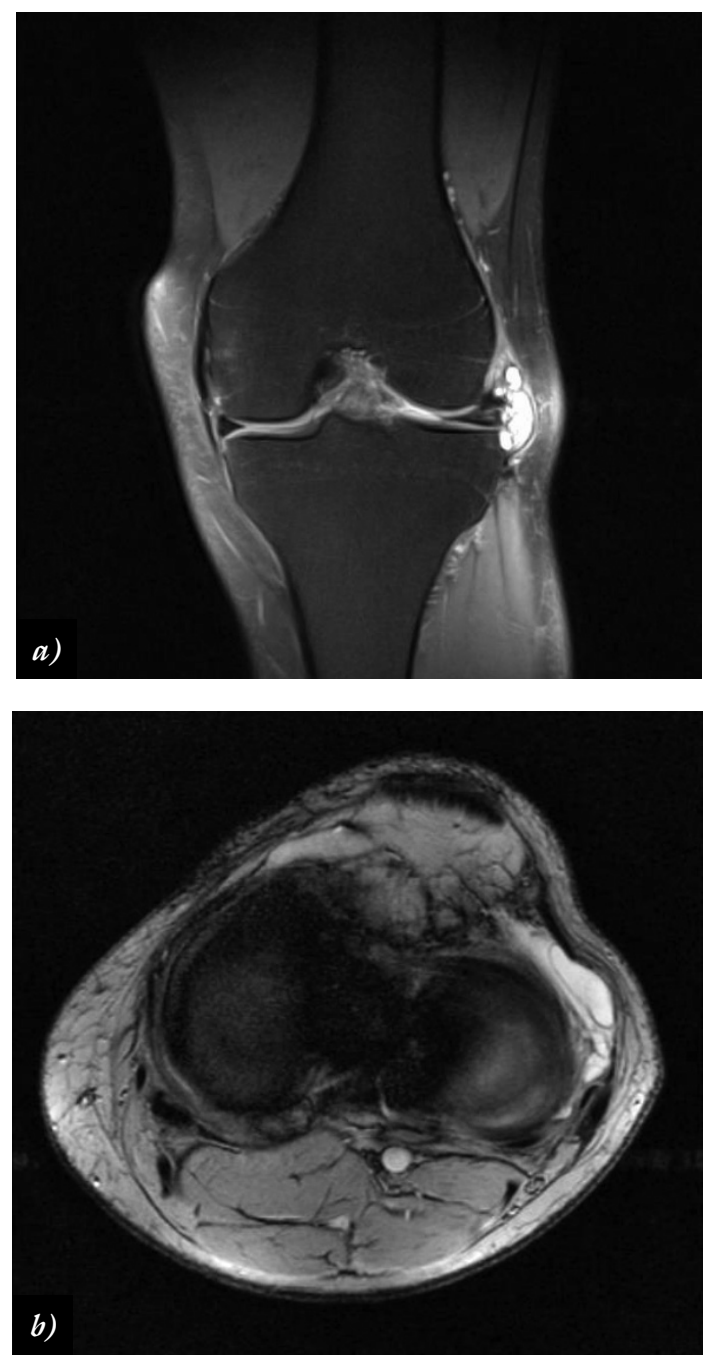

\begin{tabular}{l|l} 
1/a, b ábra & Bal térd PDFS coronalis, T2 axiális MR-felvétele, ízületi résből
\end{tabular} előtüremkedő lateralis meniscus cysta

MR = mágneses rezonancia; PDFS = zsírelnyomásos protondenzitású szekvencia 

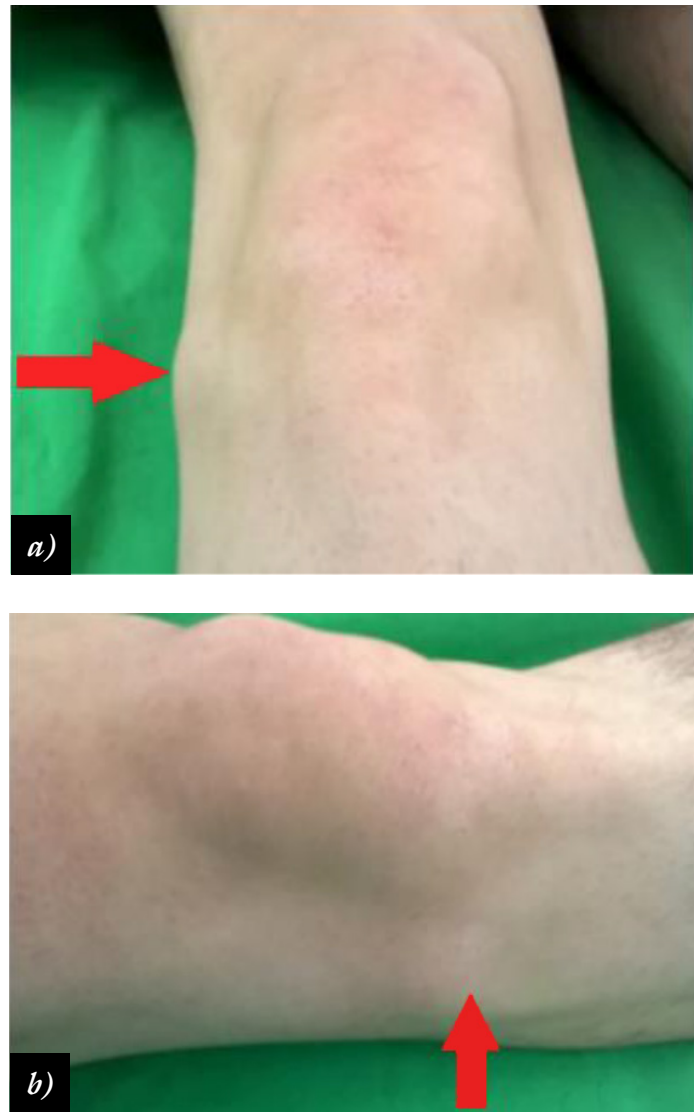

2/a, b ábra | Lateralis meniscus cysta klinikai megjelenése

A meniscustesztek negatívak voltak. A kivizsgálási protokollnak megfelelően kétirányú röntgenfelvételt készítettünk, melyen kóros csontszerkezeti eltérést nem találtunk.

Az MR-vizsgálat egyértelműen kimutatta a lateralis ízületi résből kiinduló, a meniscusszal összefüggő cystát (1/a és $1 / b$ ábra).

\section{Második eset}

Szintén fiatal, 31 éves férfi beteg, aki az előzőhöz hasonló klinikai tünetekkel kereste fel ambulanciánkat, azzal a különbséggel, hogy traumás előzményre nem emlékezett. Fizikális vizsgálata során hasonló lokalizációban jól látható és tapintható volt a lágyrész-terime $(2 / a$ és $2 / b$ ábra). A meniscustesztek pozitívak voltak, és mindez teljes fájdalmatlan mozgástartománnyal járt. Kétirányú röntgenfelvételen a terimének megfelelően a tibia lateralis condylusán csonterózió volt látható (3/a és 3/b ábra). $\mathrm{Az}$ ezt követően elvégzett MR-vizsgálat egyértelmúen kimutatta a lateralis tibiacondylusba erodáló meniscuscystát (4/a és 4/b ábra).

Klinikai és radiológiai leletek alapján mindkét esetben artroszkópiát végeztünk, melynek során a lateralis meniscus elülső szarvának horizontális szakadását találtuk.

Mivel a meniscusszakadások egyik esetben sem közlekedtek a cystával, és az intaarticularis dekompresszió sem
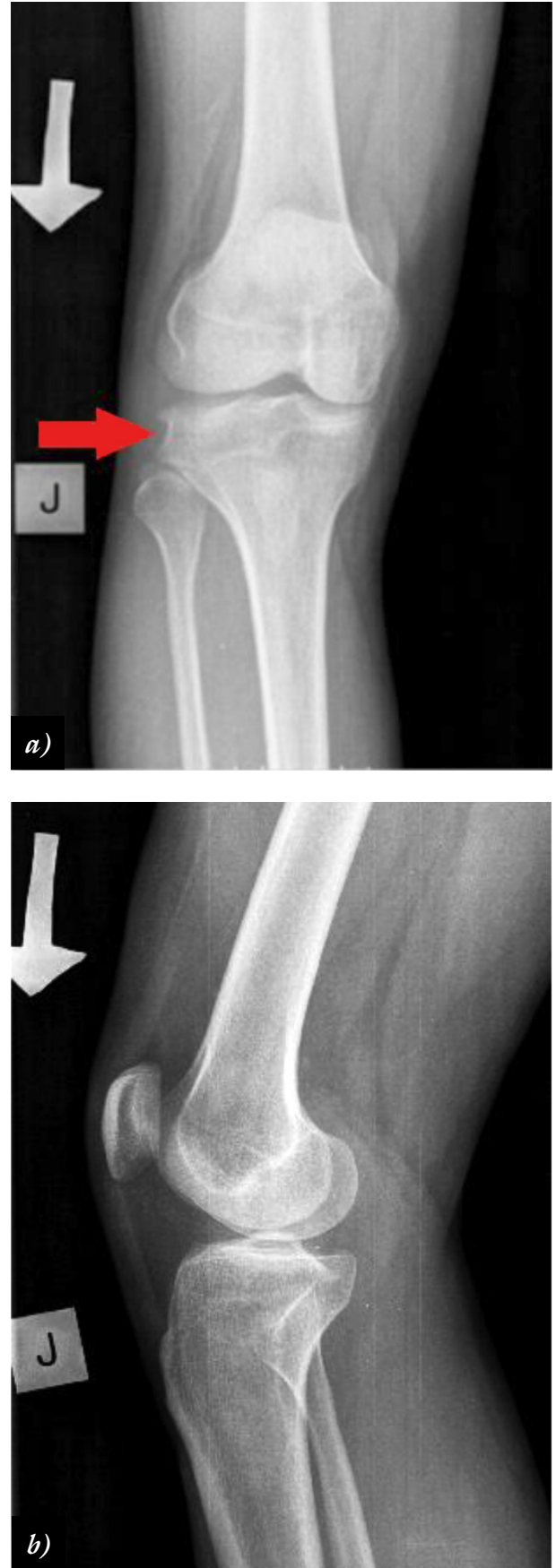

\begin{tabular}{l|l}
$3 / a, b$ ábra & $\begin{array}{l}\text { Jobb térd kétirányú röntgenfelvétele, lateralis tibiacondylus eró- } \\
\text { zió }\end{array}$
\end{tabular}

volt kivitelezhető, a meniscuscysták direkt lateralis feltárásból történő eltávolítása mellett döntöttünk.

A posztoperatív szakban a betegeket gyógytornász vezetésével, 1-1 pár könyökmankóval fokozatos terhelés mellett mobilizáltuk, majd otthonukba bocsátottuk. A mútétet követóen mindkét beteg teljesen panaszmentessé vált.

\section{Harmadik eset}

60 éves férfi beteg, akinél 2-3 évvel a felvételét megelőzôen jelent meg a bal oldali térdízület lateralis oldalán 

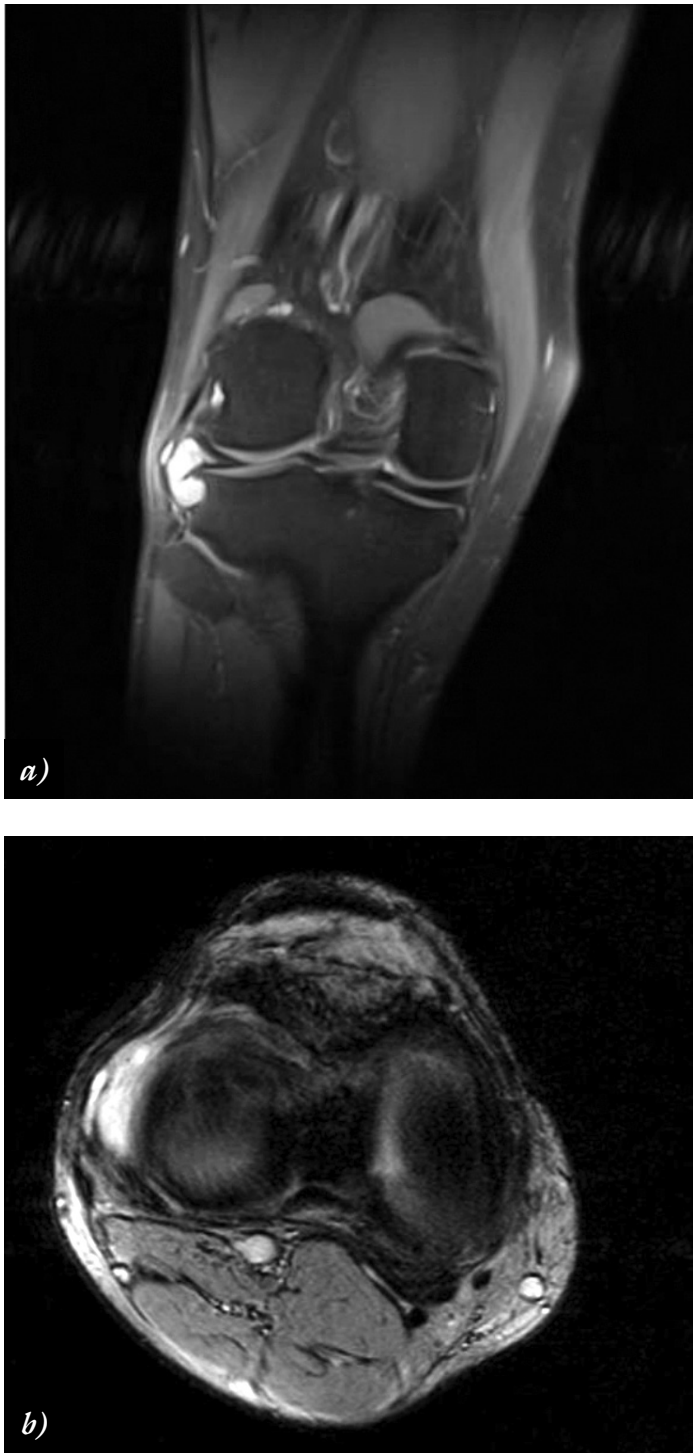

4/a, b ábra

obb térd PDFS coronalis és T2 axiális MR-felvétele a tibiacondylus erózióját okozó lateralis meniscus cystával

$\mathrm{MR}=$ mágneses rezonancia; PDFS = zsírelnyomásos protondenzitású szekvencia

egy fájdalmatlan duzzanat, mely fokozatosan diónyi méretűvé nőtt. Fizikális vizsgálata során a térdízület felett, anterolateralisan diónyi ballotálható terime volt tapintható; az ízület mozgástartománya teljes volt, az ízületi résekben enyhe nyomásérzékenységet jelzett. Betegünknél a fizikális lelet és panaszrendszer alapján az előző két esethez hasonlóan a lateralis meniscus cysta merült fel bennünk elsődleges diagnózisként.

A kivizsgálási protokollnak megfelelően kétirányú röntgenfelvételt készítettünk, melyen az ízületi rés minimális beszúküulésén, valamint az ízület melletti meszes felrakódásokon kívül más eltérést nem találtunk $(5 / a$ és $5 / b$ ábra).

Az MR-vizsgálat azonban nem lateralis meniscus cystát, hanem multilocularis ganglion cystát igazolt a subcutan zsírszövetben ventrolateralisan, illetve a Hoffazsírtestben, valamint a lateralis retinaculum rétegeiben
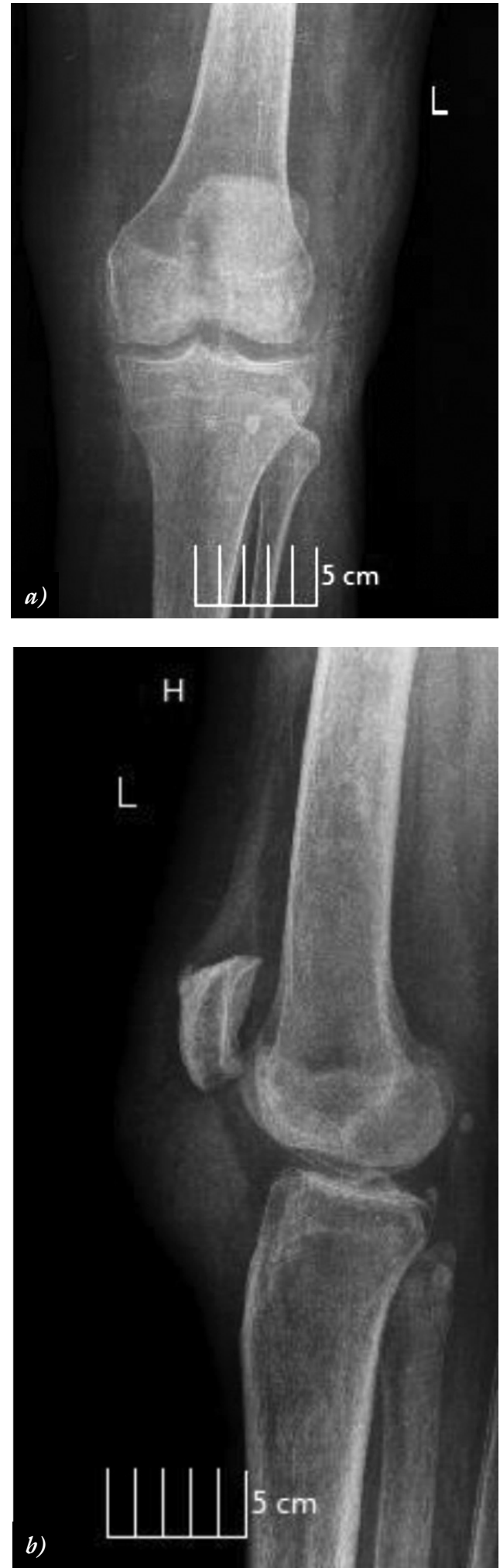

5/a, b ábra $\mid$ Bal térd kétirányú röntgenfelvétele minimális ízrésszúkülettel, valamint szabad ízületi testek

két, a ganglioncystával összefüggő, valószínúleg a patellaporcból származó szabad ízületi testet írt le $(6 / a, 6 / b$ és $6 / c a ́ b r a)$.

Ezt követően a térdízület artroszkópiáját végeztük el, melynek során a patellofemoralis ízületben grade 4 ., a 

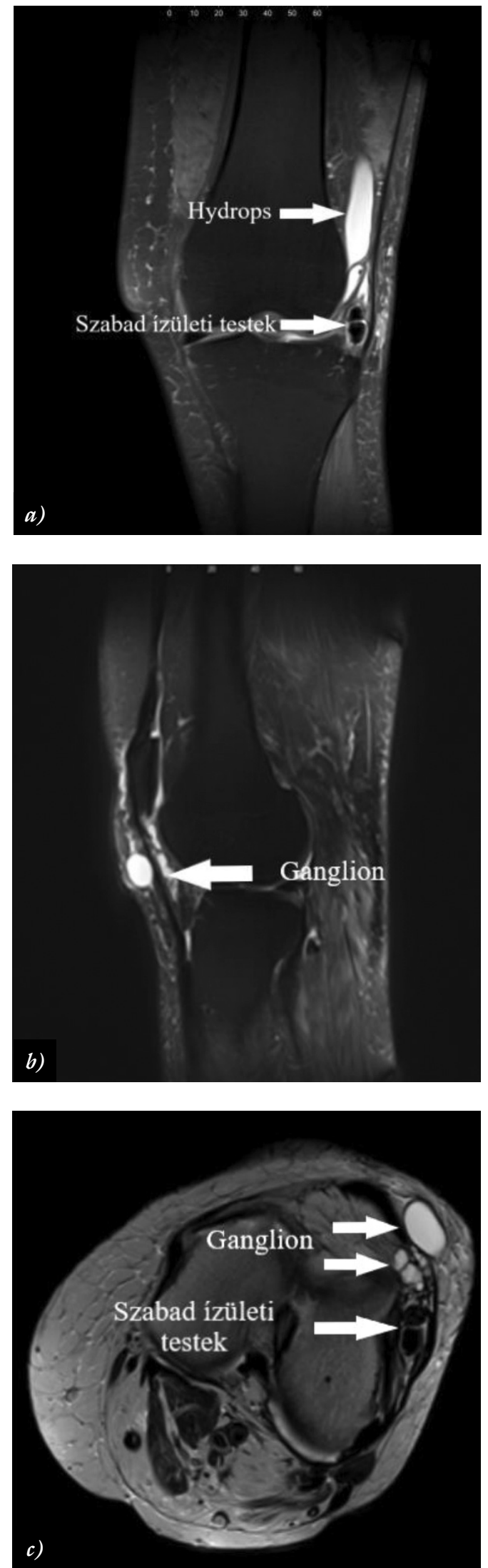

6/a, b, c ábra $\mid$ Bal térd T2 FS coronalis és sagittalis, valamint T2 axiális MR felvétele, multilocularis ganglion cysta, a lateralis recessusban 2 darab szabad ízületi testtel

$\mathrm{MR}=$ mágneses rezonancia medialis femorotibialis ízületben grade 3-4., a lateralis femorotibialis ízületben grade 2-3. chondropathiát találtunk; a meniscusok épek voltak. Mivel sem az ízületi szabad testek, sem a ganglioncysta nem volt látótérbe hozható, direkt lateralis feltárásból eltávolítottuk a 2 darab szabad testet, valamint a többrekeszes cystát is; a kivett mintát szövettani vizsgálatra küldtük, mely gangliont igazolt.

A posztoperatív szakban a beteget gyógytornász vezetésével, 1 pár könyökmankóval fokozatos terhelés mellett mobilizáltuk, majd otthonába bocsátottuk. A beteg jelenleg panaszmentes.

\section{Megbeszélés}

A lateralis térdízületi duzzanatok megjelenésük, atípusos tüneteik alapján, valamint relatíve gyors növekedésük miatt differenciáldiagnosztikai problémát jelenthetnek.

Ebben a lokalizációban irodalmi közlések alapján a következő tumoros vagy tumorszerü elváltozások jönnek szóba: ganglion, lipoma, synovialis myxoma, meniscalis vagy parameniscalis cysta, synovialis cysta, pigmentált villonodularis synovitis, synovialis haemangioma, aneurizma, synovialis sarcoma és synovialis chondromatosis [18].

A térd körüli cystosus elváltozások gyakori klinikai problémát jelentenek, melyeket számos radiológiai módszerrel értékelhetünk, beleértve a különböző artrográfiás módszereket, az ultrahangot és a CT-t, azonban minden technikának speciális korlátai lehetnek. Az ultrahang kiválóan alkalmas az ízületen kívüli, folyadékkal telt struktúrák vizsgálatára. Elérhetősége miatt általában a legelső alkalmazott modalitások között van, hátránya, hogy csak korlátozottan képes megítélni az ízületen belüli eltéréseket és a cysták intaarticularis struktúrákkal való kapcsolatát.

A CT csak korlátozott lágyrészkontraszt-felbontással rendelkezik, és az intraarticularisan elhelyezkedő cystákat a környező ízületi struktúráktól, folyadéktól nem tudja elkülöníteni, valamint nem tudja kimutatni a meniscusszakadásokat. Artrográfiával az ízülettel közlekedő cysták elkülöníthetők, de ez szemiinvazív technika, és kevés információt nyújt a nem kommunikáló cystákról. Az MR értéke a csont- és lágyrész-elváltozások, valamint a térdbetegségek diagnosztikájában jól dokumentált. Szendrôi és mtsai a metasztázisok korai stádiumban történő felismerésében a CT, a PET és az izotópdiagnosztika mellett felhívják a figyelmet a teljestest-MR-vizsgálat jelentőségére is [19]. Lazáry és mtsai a gerincmetasztázisok okozta instabilitás diagnosztikája és kategorizálása (SINS) kapcsán hangsúlyozták a korrekt MR-diagnosztika jelentőségét [20].

Az MR kiváló lágyrészkontraszt-felbontással bír, és segítségével noninvazívan és ionizáló sugárzás nélkül is lehetőség nyílik a térdízületben és a környezetében lévő cystosus elváltozások karakterizálására, valamint segítségével kimutatható az esetleges társuló vagy a cystát kivál- 
tó patológia is. Az MR-hez képest az ultrahang szenzitivitása és specificitása is jelentősen elmarad, így a parameniscalis cysta hátterében lévő meniscusszakadásokat kizárólag MR-rel kell vizsgálni [21].

A cystosus elváltozások az MR-en a folyadékhoz hasonlóan jelentősen fokozott jelintenzitásúak hosszú TR/ TE, T2-súlyozású méréseken. A T2-súlyozású mérések zsírelnyomással való párosítása fokozza a kontrasztot, így a folyadékkal kitöltött cysták jól elkülönülnek a környező zsírszövettől. A synovialis és ganglioncysták fala a legtöbbször egyenletes vastagságú, és kocsonyás anyaggal vannak kitöltve. A cysták jelmenetét a fehérjetartalom, bevérzés vagy infekció is befolyásolhatja, melyek színessé tehetik az MR-megjelenést [22].

Amennyiben a cysta MR-vizsgálaton heterogén jelmenetü, vagy szolid bennéket tartalmaz, a kontrasztanyag alkalmazása az egyéb folyamatoktól (például synovialis sarcoma) való elkülönítéshez szükségessé válhat [22, 23].

A meniscuscystákat a leggyakrabban artroszkópos meniscectomiával és percutan vagy artroszkópos cystectomiával kezelik [24, 25]. Ha a meniscusszakadás egyértelmúen megnyílik ízület felé, akkor artroszkópos parciális meniscectomia és cystadekompresszió indikált. Ha a szakadás nem közlekedik az ízülettel, akkor is keresni kell mindkét meniscus felszínén a szakadás jeleit, ezután pedig nyílt cystectomiát és meniscusvarratot célszerú végezni lateralról medialra [1].

A cysták kezelhetők túbiopsziás aspirációval és szteroidinjekcióval is [24].

$\mathrm{Az}$ intaarticularis ganglion cysták számos kezelési módja ismert. Spontán méretcsökkenését is leírták [26]. Ultrahang- vagy CT-vezérelt percutan aspirációval is kiváló eredményeket értek el [27]. Bisicchia és mtsai ugyanakkor az infrapatellaris ganglion kiújulásáról számoltak be ultrahangvezérelt aspiráció után [28].

Manapság az intraarticularis cysták artroszkópos eltávolítása a fó irányvonal, bár beszámoltak artroszkópos kezelést követően is cystakiújulásról [29]. Az infrapatellaris zsírszövetből kiinduló ganglion artroszkópos eltávolítása során nehézkes lehet a cysta elérése, ennek ellenére Yang és mtsai sikeres eltávolításról számolnak be [4].

Természetesen az infrapatellaris ganglion cysta nyílt feltárása után sem csökken a kiújulás valószínúsége nullára, de ahogy az elóbbi irodalmi adatok is említik, artroszkópos kezelést követően magas a kiújulási ráta [29]. Nikolopoulos és mtsai a fentiek miatt a nagyméretű ganglioncysták nyílt sebészi teljes reszekcióját javasolják, mely minimalizálja a kiújulás lehetőségét. Másrészről kis laesiókra az artroszkópos kezelés szerintük sokkal alkalmasabb, mivel ezek közvetlenül a synoviumban fekszenek [30].

Összefoglalva tehát, a lateralis térdízületi lágyrész-terimék ritkák, klinikai megjelenésük, aspecifikus tüneteik alapján fizikálisan nem különíthetők el egymástól. Diagnosztikájuk mindenképpen MR-vizsgálaton alapul. Köz- leményünkben az egyik lehetséges elváltozásnak, a meniscalis, illetve ganglioncystának a jelentőségére kívántuk felhívni a figyelmet.

Annak érdekében, hogy a betegeket megkíméljük a felesleges mütéti beavatkozásoktól (például biopszia, inkomplett reszekció, a folyamat kiújulása), javasoljuk az MR-vizsgálat elvégzését, és kérdéses esetben a radiológus kollégával való konzultációt.

Anyagi támogatás: A közlemény megírása anyagi támogatásban nem részesült.

Szerzôi munkamegosztás: Sz. K.: A betegdokumentációk összegyújtése, áttekintése, a kézirat megszövegezése. G. O.: Az MR-vizsgálatok áttekintése, leletezése, az MR-képanyag kiválasztása, a kézirat megszövegezése. T. P.: A hipotézis felállítása, a munkafolyamat ellenőrzése, szakmai segítségnyújtás, a kézirat megszövegezése. A cikk végleges változatát valamennyi szerző elolvasta és jóváhagyta.

Érdekeltségek: A szerzőknek nincsenek érdekeltségeik.

\section{Irodalom}

[1] Hulet C, Souquet D, Alexandre P, et al. Arthroscopic treatment of 105 lateral meniscal cysts with 5-year average follow-up. Arthroscopy 2004; 20: 831-836.

[2] Bui-Mansfield LT, Youngberg RA. Intraarticular ganglia of the knee: prevalence, presentation, etiology, and management. Am J Roentgenol. 1997; 168: 123-127.

[3] Kim MG, Kim BH, Choi JA, et al. Intra-articular ganglion cysts of the knee: clinical and MR imaging features. Eur Radiol. 2001; 11: 834-840.

[4] Yang JH, Kim TS, Lim HC, et al. Endoscopic excision of a ganglion cyst in an infrapatellar fat pad extending into the subcutaneous layer. J Orthop Sci. 2012; 17: 654-658.

[5] Takahashi T, Osawa T, Uemura T, et al. A ganglion cyst arising from the infrapatellar fat pad of the knee: a case report. Clin Orthop Surg. 2011; 46: 975-977.

[6] Nicaise A. Ganglion articulare du genou. Rev Chir. 1883; 3 : 463-465.

[7] Ebner A. Ein Fall von Ganglion am Kniegelenksmeniskus. Münch Med Wochenschr. 1904; 51: 1737-1739.

[8] Caan P. Cyst formation (ganglion) in the anterior cruciate ligament of the knee. Dtsch Z Chir. 1924; 186: 403-407.

[9] Anderson JJ, Connor GF, Helms CA. New observations on me niscal cysts. Skeletal Radiol. 2010; 39: 1187-1191.

[10] Ferrer-Roca O, Vilalta C. Lesions of the meniscus. Part II: Horizontal cleavages and lateral cysts. Clin Orthop Relat Res. 1980; 146: 301-307.

[11] Campbell SE, Sanders TG, Morrison WB. MR imaging of meniscal cysts: incidence, location, and clinical significance. Am J Roentgenol. 2001; 177: 409-413.

[12] Blair TR, Schweitzer M, Resnick D. Meniscal cysts causing bone erosion: retrospective analysis of seven cases. Clin Imaging 1999; 23: 134-138.

[13] Janzen DL, Peterfy CG, Forbes JR, et al. Cystic lesions around the knee joint: MR imaging findings. Am J Roentgenol. 1994; 163: 155-161

[14] Drosos GI, Pozo JL. Large extrasynovial intracapsular ganglia of the knee: a report of 3 cases. Arthroscopy 2005; 21: 1362-1365. 
[15] Feldman F, Johnston A. Intraosseous ganglion. Am J Roentgenol Radium Ther Nucl Med. 1973; 118: 328-343.

[16] Kang CN, Kim DW, Kim DJ, et al. Intra-articular ganglion cysts of the knee. Arthroscopy 1999; 15: 373-378.

[17] Szendrói M, Sápi Z, Pápai Zs. (eds.) The diagnosis and treatment of malignant soft-tissue tumors. [Malignus lágyrésztumorok diagnosztikája és kezelése. Térdtájéki lágyrész-sarcomák sebészete.] Medicina Könyvkiadó, Budapest, 2017; pp. 102-103. [Hungarian]

[18] Kaempffe F, D'Amato C. An unusual intra-articular ganglion of the knee with interosseous extension. A case report. J Bone Joint Surg Am. 1989; 71: 773-775.

[19] Szendrói M, Kiss J, Perlaky T, et al. Change of paradigm in the surgical treatment of metastatic diseases of bone. Part I. Bony metastases of the extremities and pelvis. [Paradigmaváltás a csontmetasztázisok sebészetében I. Végtagi és medencelokalizációjú áttétek.] Orv Hetil. 2017; 158: 1563-1569. [Hungarian]

[20] Lazáry Á, Szövérfi Zs, Varga PP. Change of paradigm in the surgical treatment of metastatic diseases of the bone. Part II. Treatment of spinal metastases. [Paradigmaváltás a csontmetasztázisok sebészetében II. Gerincmetasztázisok kezelése.] Orv Hetil. 2018; 159: 297-302. [Hungarian]

[21] Azzoni R, Cabitza P. Is there a role for sonography in the diagnosis of tears of the knee menisci? J Clin Ultrasound 2002; 30: $472-476$.

[22] Beaman FD, Peterson JJ. MR imaging of cysts, ganglia, and bursae about the knee. Magn Reson Imaging Clin N Am. 2007; 15: $39-52$.
[23] Liang C, Mao H, Tan J, et al. Synovial sarcoma: magnetic resonance and computed tomography imaging features and differential diagnostic considerations. Oncol Lett. 2015; 9: 661-666.

[24] Lantz B, Singer KM. Meniscal cysts. Clin Sports Med. 1990; 9: 707-725.

[25] Reagan WD, McConkey JP, Loomer RL, et al. Cysts of the lateral meniscus: arthroscopy versus arthroscopy plus open cystectomy. Arthroscopy 1989; 5: 274-281.

[26] Patel SJ, Kaplan PA, Dussault RG, et al. Anatomy and clinical significance of the horizontal cleft in the infrapatellar fat pad of the knee: MR imaging. Am J Roentgenol. 1998; 170: 15511555 .

[27] Resnick D. Internal derangements of joints. In: Resnick D. (ed.) Diagnosis of bone and joint disorders. WB Saunders, Philadelphia, PA, 1995; pp. 3063-3069.

[28] Bisicchia S, Savarese E. Infra-patellar fat pad cysts: a case report and review of the literature. Muscles Ligaments Tendons $\mathrm{J}$. 2013; 2: 305-308.

[29] Weber D, Friederich FN, Nidecker A, et al. Deep posterior knee pain caused by ganglion of the popliteus tendon - a case report. Knee Surg Sports Traumatol Arthrosc. 1996; 4: 157-159.

[30] Nikolopoulos I, Krinas G, Kipriadis D, et al. Large infrapatellar ganglionic cyst of the knee fat pad: a case report and review of the literature. J Med Case Rep. 2011; 5: 351.

(Szuper Kinga dr., Pécs, Akác utca 1., 7632 e-mail: drszuper.kinga@gmail.com)

\section{Az Orvosi Hetilap 2019, 160, 360. oldalán (9. szám) megjelent OH-Kvízre egy helyes megfejtés érkezett.}

A beküldő: Dr. Bíró László (Budapest).

A nyertesnek szívböl gratulálunk.

A nyereményét - egy, az Akadémiai Kiadó webáruházában kedvezményes vásárlásra jogosító kupont - e-mailen küldjük el.

A cikk a Creative Commons Attribution 4.0 International License (https://creativecommons.org/licenses/by/4.0/) feltételei szerint publikált Open Access közlemény, melynek szellemében a cikk bármilyen médiumban szabadon felhasználható, megosztható és újraközölhető, feltéve, hogy az eredeti szerző és a közlés helye, illetve a CC License linkje és az esetlegesen végrehajtott módosítások feltüntetésre kerülnek. (SID_1) 